\title{
ADHESIONS OF THE SOFT PALATE TO THE POSTERIOR PHARYNGEAL WALL; A SUCCESSFUL SILVER PLATE METHOD OF TREATMENT.
}

\author{
Dr. Franklin HazléiIULS'́, Baltimore, Md.
}

'The most common cause of achesion of the soft palate to the posterior wall of the pharynx is syphilis in the tertiary stage. Adhesion is relatively frequent in the hereditary form of lues. Rhinoscleroma, of rare occurrence in this country, is mentioned as the next most important etiological factor inducing palatal adhesions. As less frequent causes may be regarded diphtheria, lupus, ${ }^{1}$ and pemphigus. Avellis" reported a very rare lesion due to the last mentioned disease, a palatal adhesion so near complete that only a fine canal persisted just back of the uvula. Three similar cases had been reported previously by Schroctter," Iandgraf," and Steffan," respectively. Traumatic aclhesion reported by Konig," occurred in a little girl of eight years following operation for adenoids. Monod ${ }^{21}$ clescribed a case of cleft palate in a man 63 years old, in whom the two lateral parts of the palate were adherent to the posterior pharyngeal wall, and the posterior pillars of the fauces no longer visible as distinct structures. This condition he regarded as congenital.

Complete adhesion is really rare. In practically every case, there is a small residual opening connecting the naso-pharynx with the pharynx. A number of complete adhesions are, however, mentioned in the literature. Hajek reported operation upon five such cases. Foster, McDougall, Hartman, ${ }^{10}$ Roy, ${ }^{11}$ Lichtwitz, ${ }^{12}$ and a few others, reported cases of total adhesion. Cartaz, ${ }^{13}$ reporting on one case of his own, collected 39 from the literature. Lichtwitz, while reporting his case as one of total adhesion, admitted the presence of a small fistula. In Schroetter's statistics, quoted by Lieven, ${ }^{14}$ complete adhesion occurred in 0.3 per cent of the cases of luetic scarring.

Lieven classifies the cases according to extent of adliesion, into first grade, adhesion between the salpingo-pharyngeal fold and the posterior wall of the palato-pharyngeal arch; second grade, adhesion complete except for a perforation in place of or near the uvula; third grade, total adhesion. The soft palate may be greatly malformed. The nasopharynx may be more or less filled 
with fibrous bands, which at operation are broken down or cut through with difficulty.

The symptoms are largely those of nasal obstruction, and accordingly vary in severity in proportion to the extent of the lesion. Consequently, greater or less difficulty in blowing the nose, dryness of the throat due to constant mouth-breathing, anosmia, accumulation of the secretions in the nasal passages, muffled voice, deafness, headsounds, dyspnea, night terrors, aprosexia nasalis, laryngitis, tracheitis, bronchitis may be expected as prominent features of the sympomatology.

Treatment is mainly directed, after loosening or cutting through the adhesions, toward preventing readhesion and by a few operators toward preventing in as great measure as possible further contracture of the scar tissue of the soft palates and pillars of the fattces.

Fajek advised operation under cocain anesthesia, with the line of cleavage made as close to the posterior pharyngeal wall as possible, thereby saving the greatest amount of palatal tissue. The cut was made upon a sound introduced through the nose. The operation was completed to the point of separating the fibrous strands in the nasopharynx, in scveral sittings, the wound being packed with gauze during the three to four day intervals between sittings. Hajek then introduced a rubber plate (first used by v. Beregszaszy), which was left in one or two days according to the sensitiveness of the patient, then removed and replaced at intervals of a clay until healing occurred. Hajele states that after healing occurs, the palate should be frequently stretched by pulling upon it with a uvula hook.

Lieven proposed an ingenious method of combating, at the same time, the tendency to readhesion and contracture of the scarred tissue of the palate. This consisted in passing daily into the nasopharynx a tiny rubber bag which could be infated through a small rubber tube lying in the nose, to any desired pressure, and left in for a varying length of time, according to the indications. This method the writer tried on a paticnt, a young woman with only a tiny fistula persistent between the pharynx and nasopharynx. The tip of a rubber finger was tied securely to a metal connection, a rubber catheter, passed through the nose into the pharynx, was drawn out through the mouth and slipped on the other end of the metal connection. The improvised rubber bag was pulled up into the nasopharynx by 
gentle traction on the catheter, inflation accomplished, using an atomizer bulb, and a pinch-cock applied to the catheter. This treatment was used claily until the patient refused further attendance, the inflated bag being left in for several hours at a time. While feasible and attended, as far as we were able to go, with some degree of success, the method was certainly quite uncomfortalsle to the patient.

Several authors mention the use of hollow obturators fastened to dental plates to maintain the patency of the nasopharyngeal passage. Cardoux, ${ }^{15} \mathrm{Kuhn},{ }^{10}$ McDougall, ${ }^{9}$ and Schadle ${ }^{17}$ made use of this principle. Hamilton, ${ }^{18}$, Foster ${ }^{8}$ and Spencer ${ }^{10}$ employed some form of bougie.

The writer's second case had almost a total adhesion, practically preventing breathing through the normal passage, but anteriorly in the soft palate there was a perforation through which the patient got an insufficient amount of air. When this palatal perforation was occluded by a cotton plug, the patient had a disagreealble sense of suffocation. As the method of treatment described above, namely, dilatation by means of an. inflatable rubber bag in the nasopharynx, had been umpleasant to the patient, the writer desired to try in the second case to prevent readhesion, the introduction into the nasopharynx of a thin silver plate, having in mind the known bactericidal effect of silver. This should be less irritating than any other means and consequently longer borne.

At the operation done under ether anesthesia given through the Kuhn peroration intubation tube, ${ }^{20}$ the palatal adhesions were cut through keeping as close to the posterior pharyngeal wall as possible, and adhesions in the nasopharynx partly cut through and partly loosened by the finger. The palatal perforation mentioned above was freshened on the edges and closed by suture. The thin silver plate was trimmed with scissors to the required size, approximately $3 \mathrm{~cm}$. square, the sharp corners rounded slightly. Into one of several small holes in the plate, a silver wire was attached and the loose end of the wire then fastened to a rubber catheter passed through the nose into tine mouth. Traction was then made on the catheter and with the aid of a little manipulation from the pharyngeal side, the plate drawn sutgly into the nasopharynx. The wire, holding the plate in position, was fastened to the cheek by adhesive plaster.

The plate was borne by the patient without removal for eighteen days with practically no discomfort. When removed, the 
patient could breathe freely through the nasal passages. This patency still persisted three years later. The patient has a nasal twang to the voice owing to the imperfect action of the scarred palate, exact approximation of the palate to the posterior pharyngeal wall not being possible.

This method is presented not as one which will restore to normal action more or less scarred palatal structures, but one which, from the standpoint of the operator, is easier of application and, from that of the patient, freer of attendant discomforts than other methods that have been used. It would seem that very little can be accomplished toward preventing further contraction of the loosened palate tissue, but the prevention of reaclhesion is readily assured by this method.

BIBLIOGRAPIIY.

1. P. Hemank: Handbuchd. Lar. Bd. 11, S. 468.

2. Averris: Muench. Med. Wochenschr., 1900, xlvi1, 321-323.

3. Scmmontwan: Jahresbericht, 1871-1873.

4. LandgRaF: Bertiner Klin. Wochenschr., 1891.

5. Sterpax: Zehenders Monatsblatt, 1884.

6. Konsta: Archiv. internat. de laryngol., Paris, 1909, xxvil, 898-901.

7. HajeK: Internat. 7lin. Rundschau, Wien, 1892, vi, 1385-1388; also, Allgemein. Weiner med. Ztg., 1897, xli1, 13.

8. Fos'ser: Med. and Surg. Reporter, Phila., 1891, 1xiv, 385.

9. McDougats: Liverpool Med. Shir. Jour., 1903, xxili, 295.

10. Haktuan: Ztschr. f. Ohrenheil, Wiesbaden, $1889, \mathrm{xx}, 59$.

11. RoY: Ala. Med. Jour., Birmingham, 1902-1903, xv, 555-560.

12. Licirwitz: Ann. l. Mal. de l'oreille, an lavynx, etc., Paris, 1894, $\mathrm{xx}, 815$.

13. Cakraz: Arch. intemat, de laryngol., Paris, 1893, vi, 65-89.

14. Lisves: Muench. mea. Wochenschr. Mai, 1895.

15. Camboux: Ann. a. mal. de l'oreille, an larynx, etc., Paris, 1893, xix, 856-861.

16. Kuir: Monatsc7ur, f. O7renheilk, Berlin, 1892, xxvi, 189.

17. Scirame: St. Paul Med. Jouv., 1906, vili, 127-143.

18. Hashtos: Montreal Mel. Jour, 1894-1895, xxili, 1904.

19. Spexcen: Journal of Laryngol, London, 1898, xtil, 62.

20. Hazrenuns': Lanrigoscope, St. Louls, November, 1913.

21. Movon: Mcm. et bull. soc. ale med. et chir. de Bordeanx, 1887-1888, 344.

10S W. Saratoga Street. 